\title{
Components and Factors in Integrating Information Literacy Instruction in Elementary Education Using a Virtual Learning Environment
}

\author{
Krongkaew Kingsawat \\ Faculty of Humanities and Social Sciences, \\ Khon Kaen University, Thailand \\ pun.kaew@gmail.com \\ Kanyarat Kwiecien \\ Information and Communication Department, \\ Faculty of Humanities and Social Sciences, \\ Khon Kaen University, Thailand \\ kandad@kku.ac.th \\ Kulthida Tuamsuk (corresponding author) \\ Information and Communication Department, \\ Faculty of Humanities and Social Sciences, \\ Khon Kaen University, Thailand \\ kultua@kku.ac.th
}

\begin{abstract}
Background. Information literacy is one of the expected learning outcomes of elementary education in Thailand. However, there is no information literacy course in the elementary education curriculum, and information literacy instruction is left largely to individual teachers. A virtual learning environment is proposed for integrating information literacy instruction in course teaching. Objective. This study sought to identify components and factors that enable the integration of information literacy instruction at the elementary level using a virtual learning environment.

Method. Questionnaires were sent to a sample of elementary school teachers in Thailand. The data were analysed using exploratory and confirmatory factor analysis.

Results. The results indicated eleven components and seven factors relevant to the integration of information literacy instruction in elementary education using a virtual learning environment. The components include expected learning outcomes, learning objectives, content management, teaching methods, learning activities, learning interactions, learning resources, and learning assessment. The factors include administrators, teachers, librarians, learners, relationship between teacher and students, and technological qualities. The results of this study will be used in the development of a model for integrating information literacy instruction in course teaching using a virtual learning environment.
\end{abstract}




\section{INTRODUCTION}

Information literacy enables a person's self-learning and knowledge acquisition. Information literacy should be developed at the elementary level since it forms the foundation of education, which aims to develop fundamental skills of thinking, reading, writing, etc.

(National Education Bureau, 1999). Information literacy instruction should be incorporated in an education curriculum in accordance with curricular objectives and content, so that students can learn transferable skills in the context of each subject.

The Thai national policy has focused on improving the quality of its people to be ready for living in the knowledge-based society. Children must be prepared for the future society with strong basic knowledge along with life skills, information literacy, and lifelong learning skill. Therefore, information literacy is one of the learning outcomes at the elementary education level. However, a review of the literature shows that teaching of information literacy in elementary schools is not well designed or carefully implemented. There are no specific information literacy courses or information literacy development via other means. Information literacy might be taught integratedly in the regular courses, depending on the awareness and competence of each instructor (Saorayawiset, 2009). Teaching of information literacy in elementary education can be done via a full course in the curriculum, or integrating it into the regular course teaching. Integration of information literacy in course teaching can enhance the students' thinking and self-learning skills, in addition to information literacy skills (Maitaouthong, Tuamsuk \& Tachamanee, 2011).

A virtual learning environment (VLE) is an online instruction environment with classroom structures simulating learning procedures of a normal classroom, face-to-face interaction, student participation in learning, independent learning, and ready access to various sources of information. Instruction is flexible and the learning environment is efficient (Bruce \& Curson, 2001). Students are able to adjust and develop knowledge and understanding of the context according to their interest, enhancing their chances to develop skills, knowledge and understanding (Padmore, Hall, Hogg \& Paley, 2006). The factors that support teaching using a VLE include ease of use, the relationship between the activities and the course content, space for making comments and providing feedback, features that support collaborative learning (Lyndon \& Hale, 2014; Tiakiwai \& Tiakiwai, 2010), and tools for communication and interaction (Small, Dowell \& Simmons, 2012). In addition, a VLE has been found to help develop students' self-learning, increase the motivation of learners with learning difficulties, and create satisfaction in the learning (Barker \& Gossman, 2013). It is desirable therefore to utilise the qualities and advantages of a VLE to create a concrete information literacy process to enhance learners' life-long learning traits.

This study aimed to investigate the components and factors in the design of a virtual learning environment to enhance the integration of information literacy instruction in course teaching at the elementary education level. This is the first phase of a project to develop a teaching model for integrating information literacy instruction in the learning and teaching processes at the elementary education level using a VLE.

\section{LITERATURE REVIEW}

From a review of the literature, the following conceptual framework for this research was derived. 


\section{Information Literacy Learning Outcomes}

The aim or learning outcomes required in the development of information literacy programs were determined from the literature review. The American Library Association (1989), the Association of College and Research Libraries (2000), the Council of Australian University Librarians (2001) and many authors have given the same perspective on information literacy, which is defined as the individual's knowledge, ability and skills to efficiently obtain access to and use information in daily life. It is an important foundation for life-long learning. However, in the study of information literacy at the elementary level and in order to make the study relevant to the Thai social context, the following points were considered:

1. The national education standards focus on education for quality of life construction, integration of intellect, ethics, culture, life-long learning, providing a good foundation for children, and instilling good social membership from young. Thus, the following three standards and eleven indicators have been stipulated (Office of the General Secretary of the Education Council, 2005):

- Standard 1-five indicators of the required Thai traits as Thai and world citizens: 1) perfect physical and mental power, 2) necessary and adequate knowledge and skills for living and social development, 3) learning and self-adjustment skills, 4) social skills, 5) morals, public-mindedness, and awareness of being Thai and world citizens.

- Standard 2-three indicators for education: 1) curriculum and instruction management, and learning environment that help learners to develop naturally and to their fullest potential, 2) systematic and quality development of administrators, teachers, lecturers and education personnel, 3) institutional management.

- Standard 3-three indicators related to the means for constructing a learning society: 1) academic services and cooperation between institutions and the community towards a learning society, 2) study, research, enhancement and support of learning sources and mechanisms, 3) construction and management of knowledge at all social dimensions and levels.

2. The national curriculum of basic education (2001) stipulated the objectives or learning standards for learners to acquire the required traits which are in accordance with information literacy development. These are: 1) having creativity, curiosity, wanting to learn, loving to read and search, 2) having world knowledge, able to catch up with the changes and academic growth and advancement, having skills and potential in management, communications, and use of technology, able to adjust thinking and working methods to suit specific situations. Learners are encouraged to develop the following 5 abilities: communication ability, thinking ability, problem-solving ability, ability to use life skills, and ability to use technologies.

3. There are six indicators for information literacy standards for Thai students (Sacchanand, 2011): 1) students perceive the importance and necessity of information; 2) students know multiple sources of information and are able to use information retrieving tools; 3 ) students are able to analyse, evaluate and select information that they need; 4) students are able to compile, organise and synthesise information; 5) students are able to use information to produce work and present their work; 6) students are moral, obey laws, and have social responsibility related to information. 


\section{Integration of Information Literacy in Instruction}

Integration of information literacy in instruction refers to the development of information literacy skills and knowledge that are connected to the curriculum. Learning and evaluation take place according to the curricular objectives and content, which lead to learning experience in learners who are able to transfer knowledge and skills (Wallace, Shorten, Crookes, McGurk \& Brewer, 1999). A review of the literature reveals that integration of information literacy involves three main components (Li, 2011): 1) curricula objectives, 2) stakeholders including administrators, teachers and librarians, and 3) instruction including learning theories and information literacy, subject curriculum, expected learning outcomes, content, learning activities, teaching media, and learning evaluation. There are five steps in the process of curriculum development for integration of information literacy: 1) curricula analysis, 2) learning outcomes in information literacy, 3) content preparation and interaction process, 4) learning activities in information literacy, and 5) assessment and evaluation.

\section{The Virtual Learning Environment}

A virtual learning environment (VLE) is generally defined as an online instruction environment similar to a classroom, except that it is done through the use of computer technology. Learners are encouraged to interact and participate while learning. Integration of the VLE in instruction enables learners to acquire social, communication and critical thinking skills. The technology provides access to multiple information sources complete with components for lessons and tests. Learners are able to conduct their own learning activities according to their interest. Our literature review identified the following major components of the virtual learning environment (Britain \& Liber, 2004; JISC Committee for Integrated Environments for Learners (UK), 2000; Joint Information Systems Committee, 2000): 1) curriculum/subject content, 2) transfer/sending of information, 3) evaluation, 4) teacher's support, 5) communication and interaction, 6) following-up, 7) recording learners' account, 8) learning resources, 9) the teacher, 10) learners, and 11) other learners. In order to instill social, communication and critical thinking skills in learners, other components should be added which enable learners and the teacher to take part in interaction and communication using various online methods such as a notice-board/bulletin board, e-mail, online meeting tools, real-time cooperation tools (e.g., whiteboard), chat, file-uploading space, and calendar.

Other factors that affect learning outcomes and increase learning efficiency include: learning incentives, computer efficiency, activities and content in the lessons, meeting, information exchanging, system assistants, knowledge storing, assessment of progress, and subject reflection (Lim, 2007; Ginns, 2007; Lee, 2008; Sun, 2008; Bandit, 2007; Dadphan, Lertchalolan \& Tuamsuk, 2009). These factors can aid in designing a VLE, from monitoring interaction, content, usage capacity, accessibility, feedback, evaluation, learning activities, to communication tools, online learners' support, learning sources, existence of the teacher in the virtual classroom, technology qualities, orientation of the virtual classroom, accessibility of hardware and software, positive interaction between the teacher and learners, and potentiality enhancement (Dillenbourg, Schneider \& Synteta, 2002; Bangert, 2004). The results of literature review enabled the development of the questionnaire-the data collection tool in this study. 
Table 1. Fit indexes for factors affecting the integration of information literacy instruction using a VLE

\begin{tabular}{lll}
\hline Fit index & Criteria & Result \\
\hline$x^{2}$-test $=118.83 \mathrm{df}=97 \mathrm{p}=0.06550$ & Significant at $\mathrm{p}>0.05$ & Pass \\
$x^{2} / \mathrm{df}=118.83 / 97=1.22$ & $<2.00$ & Pass \\
CFI $($ Comparative Fit Index $)=0.99$ & $\geq 0.95$ & Pass \\
GFI (Goodness of Fit Index) $=0.96$ & $\geq 0.95$ & Pass \\
AGFI (Adjusted Goodness of Fit Index) $=0.93$ & $\geq 0.95$ & Fail \\
RMSEA (Root Mean Square Error of & $<0.05$ & Pass \\
Approximation) $=0.0252$ & & \\
\hline
\end{tabular}

\section{RESEARCH METHOD}

A questionnaire was developed to obtain elementary school teachers' opinions related to integrated information literacy teaching, standards for information literacy at the elementary education level, and virtual learning environments. The questionnaire, listed in Appendix 1, was tested on 25 elementary school teachers in Khon Kaen province to assess its validity. Cronbach's Alpha of 0.98 was obtained, which was considered acceptable.

A sample size of 385 was selected to obtain a $95 \%$ confidence interval of $\pm 5 \%$. The questionnaire was sent to 385 elementary school teachers. 329 questionnaires were returned, giving a response rate of $85 \%$. The data was analysed through exploratory and confirmatory factor analysis using the LISREL program.

Participant responses to two sets of questions in the questionnaire were analysed: 1) the components of integrated information literacy instruction using a VLE which comprised ten factors, and 2) the success factors for integrated information literacy instruction using a VLE which comprised seven factors (see Appendices 2 and 3). In step 1, exploratory factor analysis was used to analyse the relationship between the factors and their variables. This was because the proposed factors and variables in the components and the success factors were developed based on the literature review. From the results of the exploratory factor analysis, a decision was taken to change the components from ten factors to eleven factors, and eight variables were re-categorised. The dataset for the success factors remained the same. All the variables in the exploratory factor analysis had factor loading values greater than 0.30 , which according to Kerlinger (1973) is acceptable. In step 2, confirmatory factor analysis was used to identify the overall goodness of fit and path estimation of the variables in each factor. Schumacker and Lomax (2010) suggested that fit index scores for GFI, AGFI and CFI greater than 0.90 to 0.95 , and standardised RMSEA lower than 0.05 to 0.08 from the confirmatory factor analysis are acceptable. Table 1 shows that the fit indexes for factors affecting the integration of information literacy using VLE are acceptable.

\section{FINDINGS}

The respondents were made up of $60 \%$ female and $40 \%$ male. $73 \%$ of them were Bachelor degree holders. $71 \%$ were grade six teachers in medium-sized elementary schools. More than half of the respondents $(54 \%)$ have been teaching for more than twenty years.

With regard to the current status of information literacy instruction in the schools, the findings revealed that:

1. Most of the teachers have set expected learning outcomes in course teaching which relate to the following information literacy skills: identification of the study problems or topics 
(84\%), awareness of related information resources (70\%), and selection of information in accordance to the needs.

2. The teachers have worked collaboratively with the schools' librarians in their course teaching for the assignment of learning activities (64\%), development of lesson plan (61\%), and preparing the exercises and homework (60\%).

3. The teachers used most of the following teaching methods: lecture (88\%), field trip (75\%), and student-centered learning (68\%).

4. The teachers used the following learning activities in their course teaching: self-study assignments (79\%), exercise assignments (78\%), and group projects (70\%).

5. The teachers used the following information resources in their course teaching: required textbooks (94\%), primary sources (81\%), and related media and audio visuals $(67 \%)$.

Factor analysis was used to analyse the data relating to the components and factors for integrating information literacy instruction using a VLE. The factor loading values were set at 0.30 or higher (Kerlinger, 1973). The results are as follows.

\section{Components in Integrating Information Literacy Using a VLE}

Eleven components were found useful for integrating information literacy instruction using a VLE: setting expected learning outcomes, setting learning objectives, managing learning contents, instruction, teaching methods, learning patterns, learning activities, teaching and learning interactions, learning resources, learning assessment, and teaching strategies (see Appendix 2).

\section{Setting expected learning outcomes}

Elementary-level students should be led to perceive the importance and necessity of information. Students should know of and have access to multiple sources of information, and be able to use the information ethically and legally. This is consistent with the opinions of information literacy experts towards elementary-level Thai students' information literacy (Saorayawiset, 2009; Sacchanand, 2011). When we analysed the components with factor analysis however, we found two more components: 1) Setting clear problems or curricular objectives related to information literacy instruction at the elementary level, and 2) Setting objectives with a focus on former information literacy skills. Therefore, in setting expected learning outcomes, problems or curricular objectives related to information literacy must be determined at the beginning in order to clarify the expected learning outcomes. These outcomes need to be in line with the instructional processes, especially in helping students to perceive the importance of information literacy. The learning outcomes will support educational policies under the National Education Act, 1999, which states that students should be able to utilise information to develop their thinking process, critical thinking, selflearning process, their ability to make decision, solve problems, plan their education and occupation, and develop self-learning and life-long learning (National Education Bureau, 1999).

\section{Setting learning objectives}

In the setting of learning objectives, the focus should be on encouraging students to work with others in a cooperative learning style. The objectives should be clearly defined, with students directly participating in the learning process. Information literacy should be incorporated in the curriculum and assessment. In the context of curriculum development, McGee (1997) said 
that curricula objectives should arise from the requirements in the subject structure and the subject documents. $\mathrm{Li}$ (2011) said that information literacy should be one of the curriculum objectives and requirements. Teaching measures should also be considered in order to become a means for integration. In addition, standards or frame of reference in information literacy should be taken into account and incorporated appropriately in the curriculum.

\section{Managing subject content}

Subject content should be in accordance with the standard elementary education. Examples should be given for learners to understand better. The curricular content of information literacy should be incorporated with clear expected learning outcomes. However, Dillenbourg, Schneider and Synteta (2002) highlighted an important consideration when designing the virtual leaning environment-which is that content management should be standardised. It is important for researchers and developers to understand the relationship functions of the information structure-what structures, how to present, how to apply in the teaching and learning activities, and how to support interaction.

\section{Instruction}

Instruction must link the curriculum with the national educational goal or the Education Act. Information literacy objectives appropriate to elementary-level students should be stipulated. The learning outcomes should aim to develop students' moral and ethics in the legal utilisation of information. The teaching methods should be in line with the subject and link information literacy skills with the learning contents. Instruction at each grade should incorporate multiple teaching approaches, with emphases on real situations, self-learning, cooperative learning, learning from nature, and learning from practice. Assessment and evaluation should be in line with the learning activities through both performance assessment and authentic assessment (Jesadawirot, 2003).

\section{Teaching method}

The teaching method selected should be a cooperative learning method, with an emphasis on learning activities by: dividing learners into small groups in order to perform activities and exchange ideas, assigning learners to conduct study trips online to learning websites, online libraries, etc., incorporating self-learning from researching in online libraries, and demonstrating with focus on information retrieving so that learners learn from real practice. The findings were in accordance with the study by Bowler and Street (2008) who found that learners should be divided into small groups of three to ten students. The foci should be on learners' studying, researching, exchanging ideas, and giving presentations. In addition, a study by Ursin, Lindsay and Johnson (2004) showed that learners should be taught to take responsibility for learning by themselves through studying in libraries, doing exercises, assignments, and exchanging ideas so that students can acquire reasonable thinking skills.

\section{Learning patterns}

The synchronous learning pattern should be used since it has synchronous activities where learners and teacher must do the learning activities together as though the teacher is in the classroom or in front of the class. In fact, each learner contacts the teacher and other learners via the online learning system, in which information is sent and received synchronously. In 
contrast, the asynchronous learning mode does not require the teacher and learners to do the activities synchronously. The teacher will perform an activity only when students submit their work or when they contact the teacher with questions. Gedviliene and Vaiciuniene (2008) who pointed out that information literacy can improve learning when new technologies are incorporated in the instruction process. This can be divided into two types:

1. Synchronous learning, where learning activities happen at the same time. The teacher and the students must join the activities together. Then information will be sent and received synchronously, for example, in chatting, sending texts, sound, pictures, and moving pictures.

2. Asynchronous learning, where the teacher and the students are not required to join the learning activities at the same time. The learning does not require the information sender and receiver to work synchronously, for example, sending e-mail, newsgroup, information network from other websites where learners can learn any time based on their preference and potentiality (Zhao, 1996; Britain \& Liber, 2004; Bandit, 2007).

Nevertheless, a study by Dadphan, Lertchalolan and Tuamsuk (2009) found that the time and frequency of interaction do not have an impact on success in learning, notwithstanding if it is synchronous interaction or asynchronous interaction. The more important point is the quality of the teacher's or peer reflection.

\section{Learning activities}

When designing learning activities, the teacher should ensure that learners have a chance to show their opinions and react to the lesson/activity. Learners should be encouraged to draw conclusions from each topic learnt and discuss their usefulness in daily life. Activities that allow self-studying should be focused on. A variety of activities in virtual learning environments complete online classroom activities by integrating multiple information technologies with multiple teaching approaches, and this is how they are comparable to normal classroom environment (Dillenbourg, Schneider \& Synteta, 2002). Hence, when developing a virtual learning environment, activities should be designed to be in line with normal classroom learning, for example, students' attendance, orientation, question-answer sessions, exercises, etc.

\section{Learning interactions}

Learning interactions are viable through a VLE and occur among the learners and the teacher, or between one learner and another in order to communicate and enable efficient learning. Research has shown that orientation should be scheduled prior to teaching, with objectives and introduction to information literacy clearly specified. A simple question-answer session should be incorporated to stimulate learners to link the topic to be learned with the information resources that will support their learning. Learners should be encouraged to express their ideas and react to the lessons regularly. Learners at the age range of six to twelve years are under preparation in terms of physical, emotion, social, and intellectual conditions. If a child is within an environment that assists him or her to develop in all of the said aspects, it supports the child to develop an ability to adjust smoothly to any new experience, environment and the open world of knowledge (McLeod, 2009) that is accessible through advanced information technologies. These are channels for social network communication and online communities that lead to social development and a degree of interaction, provided usage is appropriate. 


\section{Learning resources}

Appropriate information resources for a VLE to enhance information literacy should be within the academic circle to support learners' interest or assignments related to each subject content. The resources should be suitable to the learners' age range and development. An electronic library can be integrated in a classroom comprising texts, sound, videos and movies, produced by the teacher or linked from external resources (Perrin, 1994). Li (2011) has pointed out that learning environments that aim to integrate information literacy skills should be provided with information resources and technologies that support retrieval as well as counselling experts.

\section{Learning assessment}

Assessment of a VLE integrated with information literacy instruction should be concrete and performed prior to and after learning. The assessment should cover information literacy and done through observation of activities and participation to demonstrate appropriate, accurate, and legal, moral and ethical use of information. This is in accordance with Fitzwater et al. (2003) who said that integration of information literacy should involve learning assessment criteria to assess the skill and knowledge of learners based on information literacy standards. The study by Maitaouthong, Tuamsuk and Tachamanee (2012) also indicated that integration of information literacy requires measuring and assessing the learning outcomes of information literacy such as assessing reports, exercises, assignments, and small group work.

\section{Teaching strategies}

After the exploratory factor analysis, this component was adjusted to comprise four subcomponents, namely:

1) The teacher and learners draw conclusions and possible daily life usage of the content after learning each topic (0.474);

2) The teacher gives orientation before the lesson by stating the objectives and giving advice on choosing the topic to research (0.553);

3) The teacher asks simple questions to stimulate learners to link the topic to the information resource that will support learning (0.524);

4) The teacher encourages learners to show ideas and react to the lesson (0.415).

These sub-components are stimulants the teacher applies to encourage, create and link knowledge for learners. Thus, we named this group teaching strategies.

\section{Success Factors Enhancing Integration of Information Literacy Instruction Using a VLE}

There are seven success factors that enhance integration of information literacy instruction using a VLE: administrators, teachers, cooperation from librarians, learners, interaction between teacher and learners, teaching and learning activities, and qualities of technology (Appendix 3).

\section{Factor related to administrators}

Administrators can have an influence on the development of information literacy in learners. Administrators must see the importance of information literacy and support it in terms of policy by stipulating information literacy as one of the learners' traits and integrating 
information literacy into different subject groups. Besides policy, administrators should also support information literacy in terms of developmental infrastructures, such as personnel, technologies, computers, and the Internet. Budget should also be allocated for improving learning resources such as the library and network technology. Previous research has shown that administrators should accept and understand the importance of integrating information literacy into mainstream education by actually promoting its use in instruction (Fitzwater et al., 2003; Harrison \& Rourke, 2006; Maitaouthong, Tuamsuk \& Tachamanee, 2012).

\section{Factor related to the teacher}

In order to develop learners to be information literate, the teacher must first see the importance of information literacy, know multiple sources of information such as information resources, library services, and information retrieval from the Internet. In this way, the teacher will be able to support the students to find what they need. The teacher should also understand and be able to integrate information literacy in the instruction. Past research has shown that integration of information literacy can only happen when the teacher who implements the curriculum is aware of the importance and necessity of information literacy ( $\mathrm{Li}, 2011$; Maitaouthong, Tuamsuk \& Tachamanee, 2012). Thus, the teacher should be given a role in curricular development since he or she is the person who implements it in the classroom and builds the learning experiences for the learners (McGee, 1997).

\section{Factor related to librarians' cooperation}

Librarians must understand the importance of information literacy and be able to integrate information literacy in instruction. Librarians know and are able to employ information technologies such as search engine, chat room, e-mail and web board. This corresponds to a study by Li (2011), who stated that stakeholders can integrate information literacy in the curriculum through communication and building relations between librarians and the teacher. The teacher and the librarians should work together to design an information literacy curriculum with the aim of integration. Maitaouthong, Tuamsuk and Tachamanee (2012) showed that the knowledge and understanding of librarians related to integration of information literacy included: understanding of its importance, conceptual framework of information literacy, understanding of their roles in development of information literacy, linking of information literacy to learning objectives and learning outcomes, and cooperation between the teacher and librarians in linking the learning contents.

\section{Factor related to learners}

In order to become information literate, learners must be able to control their own learning time well. They should share experiences with their friends. This would help in information analysis and selection of information before sharing. Learners should also be able to use information technologies such as search engine, chat room, e-mail and web board. This is in line with recent research that showed the characteristics of learners related to self-monitoring in online learning, which is an important factor in self-leaning (Dadphan, Lertchalolan \& Tuamsuk, 2009; Kim, 2005). In addition, a study of the learning experiences of students who acquired information literacy skills through a VLE by Gedviliene and Vaiciuniene (2008) showed that the transfer of knowledge, skills and attitudes in turn lead to successful selfdevelopment. However, the use of VLE in instruction requires learners' self-control. If they are not able to control themselves, the learning outcomes would not be as expected. When 
students are learning from big information sources on the Web, they can be distracted by things that are not under the topic of study. Learners may have problems in controlling or monitoring themselves; they may lack incentive and skills, or are unable to organise or select the topics or resources to learn from. The teacher has to support them in this respect (Chizmar \& Walbert, 1999; Bandit, 2007; Dadphan, Lertchalolan \& Tuamsuk, 2009).

\section{Factor related to interaction between the teacher and learners}

Interaction between the teacher and the students must be positive. Students should be able to ask and answer questions in an environment of good relationship, which will lead to success in learners' activities. Past research has found that positive interaction between the teacher and learners enable a VLE to be effective and efficient (Dadphan, Lertchalolan \& Tuamsuk, 2009; Cohen, 2002; Schrum \& Hong, 2002). Moreover, when the teacher and the students participate and communicate through multiple online systems, the latter have a chance to develop social, communicative, and critical thinking skills. Additionally, discussions should be arranged to promote critical thinking skills together with provision of online consultation time for students to interact with the teacher and with other students. If the teacher's online time is fixed and regularly scheduled, the frequent interactions will make a VLE become similar to normal classrooms. Recent research results suggest that interactions between the teacher and students in a virtual classroom with fixed time table for meeting will allow students to know when they are able to consult the teacher (Dadphan, Lertchalolan \& Tuamsuk, 2009). Similarly, the results of a study by Snell and Brown (2000) suggest that teachers should set adequate online meeting times to reduce learning problems and encourage students to be more interested in attending online classrooms. The use of technologies as tools to develop learners' information literacy is one channel of interaction between the teacher and the students, and among the students themselves. This will ultimately lead to students becoming information literate (Godwin, 2009). Students have a chance to sharpen their critical thinking skills and receive reflective practice (Johnston \& Webber, 2000). Nevertheless, we still have to take into consideration those students who dissociate themselves from others and hence do not interact with the teacher and peers. Another problem is the distraction that always plagues learners during the learning periods (Besser \& Donahue, 1996).

\section{Factor related to learning activities}

Learning activities should be varied, interesting and suitable for the learners' intellectual levels. Learners should not feel bored. Group members must attend classes and participate in activities regularly. Hence, activities should be appropriately designed: they should not be too difficult, with provision of clues to help students to answer questions. However, the use of online technologies in teaching information literacy, even though assisting students' information capacity, requires arrangement of different components that are appropriate and varied. For instance, the online activities should take into account the content design, other available information sources, supporting online systems, activity-orientation, and weekly online assignment with content that covers information literacy (Mutula, Kalusopa, Moahi \& Wamukoya, 2006). 


\section{Factor related to technologies}

Computer facilities should be compatible with high-speed Internet access that should not disconnect frequently, and should be able to respond to each student anywhere and anytime. Students should be able to link a VLE with external information sources efficiently. As Dillenbourg, Schneider and Synteta (2002) suggested, the information system should be well monitored, i.e. maintaining the structure and links, and deleting obsolete information. Lim (2007) and Lee (2008) mentioned that computer efficiency in creating contents that lead to practices, building incentives, and integrating online learning with normal instruction are important factors for learning efficiency in the context of a VLE. Therefore, application of a VLE requires consideration of the resources of the school, which should be well equipped in terms of information technologies and Internet network systems.

\section{CONCLUSION}

A summary of the research results is shown in Figure 1. Learning in a virtual learning environment (VLE), with information literacy instruction integrated in course teaching, requires attendance in classrooms similar to normal classrooms. The teacher must be present

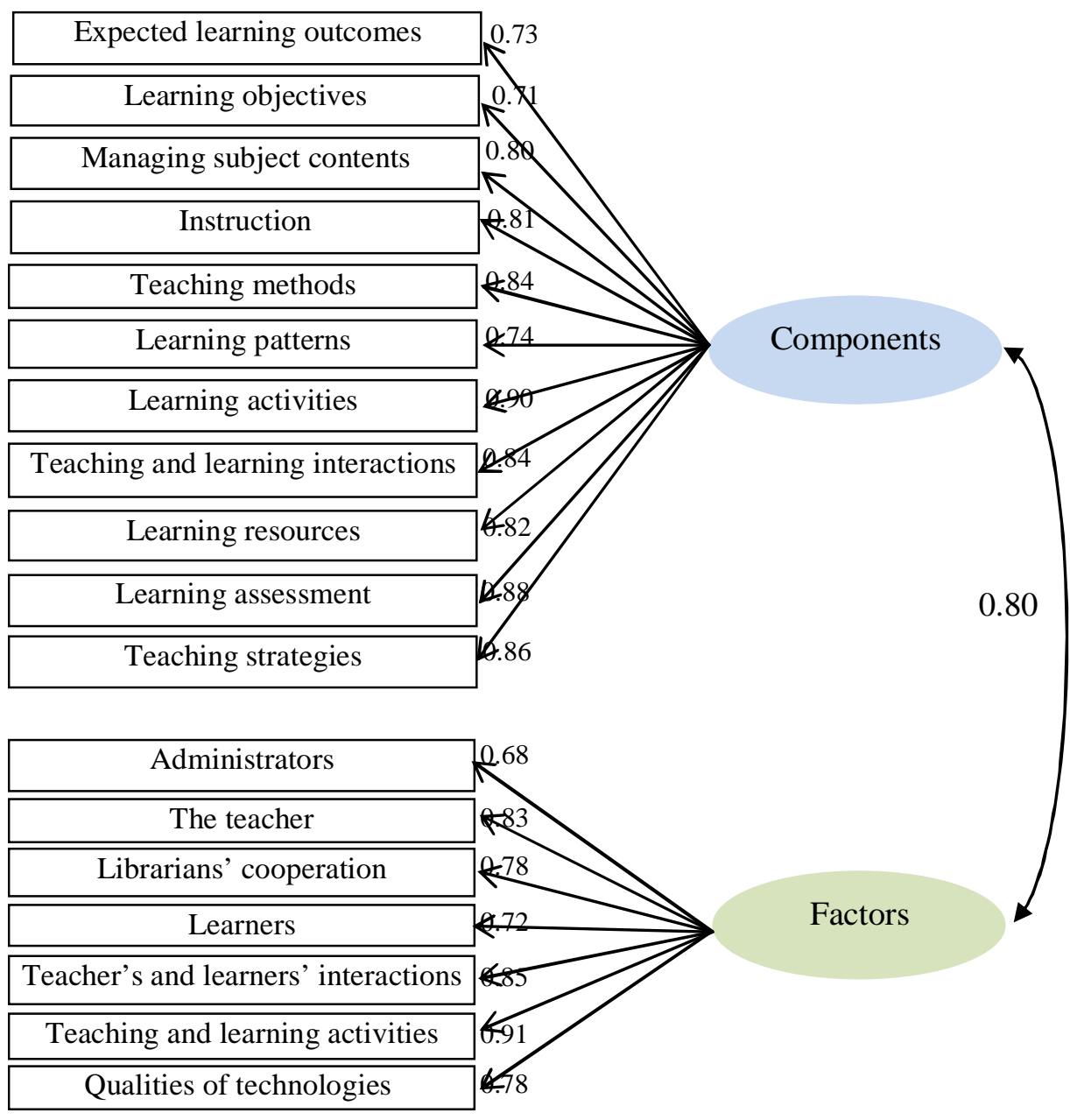

Figure 1: Results of analyses of components and factors enhancing integration of IL at elementary-education level using a VLE 
in the virtual classroom with the students and orientate them before lessons start. The learning system allows recording of attendance all through the course. However, research has shown that for elementary-level students, a teacher must be present in the real classroom in parallel with the virtual classroom, since the students are still familiar with interacting with their teacher, asking questions, and chatting about other things. Analysis of the data related to factors affecting learning outcomes using a VLE obtained a factor loading value of 0.84 for interactions between the teacher and students, and 0.83 for the teacher, indicating that the two factors greatly affect students' learning. Therefore, the teacher must realise the importance of information literacy, know information resources and be able to introduce them to the students, in order to be able to integrate them in the course teaching.

Learning activities should be designed to focus on self-researching, which must be within the scope of the subject content in the curriculum. Nevertheless, the research results indicate that information literacy skills necessary for elementary-level students are: 1) their perception of the importance and necessity of information, 2) their ability to have access to multiple sources of information, 3) their ability to use information-retrieving tools, and 4) their knowledge, understanding, and ability to use information ethically and legally. Thus, a focus should be placed on the importance of information literacy, how important it is for research and study, how it helps in solving everyday life. The activities should be designed for students to search information from different sources. Therefore, a VLE should be equipped with search engines and tools, such as links to Google for ease of access; or providing other reliable online information sources related to the subject of the course.

At the same time, ethical and legal use of information should be observed. At the elementary level, students can be assigned to do reports and provide references or bibliography of the sources they use. Activities should cover all information literacy skills, be varied, and not be too difficult. After analysing the factors affecting learning in a VLE, it was found that integration of information literacy has the highest factor loading (0.9), while learning activities have a factor loading of 0.91 , indicating that integration of information literacy using a VLE and learning activities are important factors that lead to success. Learning assessment should be performed in two parts: content assessment and information literacy assessment. When analysis was conducted on factors affecting learning outcomes from the use of a VLE, we found that assessment and evaluation is a vital component with a factor loading of 0.88 .

\section{REFERENCES}

American Library Association. (1989). Presidential committee on information literacy (final report). Chicago: ALA.

Association of College and Research Libraries. (2000). Information literacy competency standards for higher education. Chicago: ACRL. Retrieved from http://www.ala.org/acrl/standards

Bandit, A. (2007). Presenting web-based learning using learning process based on resources for critical thinking development and using information to solve problems of Walailak University Graduate Students. Doctoral thesis in Education Technology and Communications, Chulalongkorn University, Thailand.

Bangert, A. W. (2004). The seven principles of good practice: A framework for evaluating online teaching. Internet and Higher Education, 7(3), 217-232.

Barker, J., \& Gossman, P. (2013). The learning impact of a virtual learning environment: students' views. Tean Journal, 5(2). Retrieved from http://bit.1y/AtMwtr 
Besser, H., \& Donahue, S. (1996). Introduction and overview: Perspectives on ... distance independent education. Journal of the American Society for Information Science, 47(11), 801-804.

Bowler, M., \& Street, K. (2008). Investigating the efficacy of embedment: Experiments in information literacy integration. Reference Services Review, 36(4), 438-449.

Britain, S., \& Liber, O. (2004). A framework for the pedagogical evaluation of eLearning environments. Educational Cybernetics Reports Paper 2. Retrieved from http://digitalcommons.bolton.ac.uk/iec_reports/2

Bruce, J., \& Curson, N. (2001). UEA virtual learning environment_Product evaluation report. Learning Technology Group. Retrieved from http://www.uea.ac.uk/ltg/blackboard/VLEreport.pdf.

Chizmar, J. F., \& Walbert, M. S. (1999). Web-based learning environments guided by principles of good teaching practice. Journal of Economic Education, 30(3), 248-264.

Cohen, N. L. (2002). Factors related to success and satisfaction in online learning. Academic Exchange Quarterly, September 22, 2002. Retrieved from http://www.thefreelibrary.com/Factors related to success and satisfaction in online learning.-a094078154

Council of Australian University Librarians. (2001). Information literacy standards. Canberra: CAUL.

Dadphan, K., Lertchalolan, C., \& Tuamsuk, K. (2009). Impact factors on the learning achievements in a virtual classroom environment using a project-based learning approach in information literacy course teaching at higher education. T.L.A. Research Journal, 2(1), 81-92.

Dillenbourg, P., Schneider, D. K., \& Synteta, P. (2002). Virtual learning environments. In Proceedings of the 3rd Hellenic Conference on Information \& Communication Technologies in Education (pp. 3-18). Greece: Kastaniotis Editions.

Fitzwater, D., Geesaman, J., Gray, K., Kickels, C., Olberding, A., Payne, N., ... Webb, N. (2003). Information literacy across the curriculum action plan. Retrieved from http://www.cod.edu/library/services/facukty/infolit/actionplan.pdf

Gedviliene, G., \& Vaiciuniene, V. (2008). Students learning experience in the integrated information literacy course constructed in virtual learning environment. Informatics in Education, 7(1), 127-142.

Ginns, P. A. (2007). Quality in blended learning: Exploring the relationships between on-line and face-to-face teaching and learning. Internet and Higher Education, 10, 53-64.

Godwin, P. (2009). Information literacy and Web 2.0: Is it just hype? Electronic Library and Information Systems, 43(3), 264-274.

Harrison, J., \& Rourke, L. (2006). The benefits of buy-in: Integrating information literacy into each year of an academic program. Reference Services Review, 34(4), 599-606.

Jesadawirot, S. (2003). Integrated instruction. Bangkok: Book Point.

JISC Committee for Integrated Environments for Learners (UK). (2000). Managed learning environment. Retrieved from http://www.jisc.ac.uk/index.cfm?name=jclt_home

Johnston, B., \& Webber, S. (2000). Towards the information literate graduate: Rethinking the undergraduate curriculum in business studies. In K. Appleton, C. Macpherson \& D. Orr (Eds.), Lifelong learning conference: Selected papers (pp. 194-202). Rockhampton, Qld.: Lifelong Learning Conference Committee, Central Queensland University.

Joint Information Systems Committee. (2000). MLEs in further education: Progress report circular 7/00. Retrieved from

http://www.Jisc.ac.uk/index.cfm?name=news_circular_7_00 
Kerlinger, F. N. (1973). Foundations of behavioral research (2nd ed.). New York: Holt, Rinehart and Winston.

Kim, K.-J. (2005). Adult learners' motivation in self-directed e-learning. Doctoral dissertation, School of Education, Indiana University.

Lee, J. A. (2008). The relationship of e-learner's self-regulatory efficacy and perception of elearning environmental quality. Computers in Human Behavior, 24(1), 32-47.

Li, W. (2011). An information literacy integration model and its application in higher education. Reference Services Review, 39(4), 703-720.

Lim, H. L. (2007). Validating e-learning factors affecting training effectiveness. Information Management, 27, 22-35.

Lyndon, S., \& Hale, B. (2014). Evaluation of how the blended use of a virtual learning environment can impact on learning and teaching in a specific module. Higher Education Academy, 6(1), 56-65.

Maitaouthong, T., Tuamsuk, K., \& Tachamanee, Y. (2011). Development of the instructional model by integrating information literacy in the class learning and teaching processes. Education for Information, 28(2-4), 137-150.

Maitaouthong, T., Tuamsuk, K., \& Tachamanee, Y. (2012). Factors affecting the integration of information literacy in the teaching and learning processes of general education. Journal of Educational Media and Library Science, 49(2), 265-292.

McGee, C. F. (1997). Teachers and curriculum decision-making. Palmerston North: Dunmore Press.

McLeod, S. A. (2009). Jean Piaget's cognitive theory—simply psychology. Retrieved from http://www.simplypsychology.org/piaget.html

Mutula, S., Kalusopa, T., Moahi, K., \& Wamukoya, J. (2006). Design and implementation of an online information literacy module: Experience of Department of Library and Information Studies, University of Botswana. Online Information Review, 30(2), 168187.

National Education Bureau. (1999). The National Education Act, 1999. Bangkok: The Bureau.

Office of the General Secretary of the Education Council. (2005). National Education Standards. Bangkok: The Office.

Padmore, M., Hall, L., Hogg, B., \& Paley, G. (2006). Reviewing the potential of virtual learning environments in schools. Retrieved from http://osiris.sunderland.ac.uk/ cs0lha/Publications/2006/padmore-hall-hogg-paley.pdf.

Perrin, D. G. (1994). The university of the future. Education Journal, 9(2), 140-143.

Sacchanand, C. (2011). Development of information literacy standards for Thai Students. T.L.A. Research Journal, 4(1), 13-22.

Saorayawiset, P. (2009). Development of information literacy of elementary school students in Thailand. Doctoral thesis in Information Studies, Khon Kaen University, Thailand.

Schrum, L., \& Hong, S. (2002). Dimensions and strategies for online success: Voices from experienced educators. $J A L N, 6(1)$. Retrieved from http://sloanc.org/publications/jaln/v6n1/pdf/ v6n1_schrum.pdf.

Schumacker, R. E., \& Lomax, R. G. (2010). A beginner's guide to structural equation modelling. New York: Routledge.

Small, F., Dowell, D., \& Simmons, P. (2012). Teacher communication preferred over peer interaction: Student satisfaction with different tools in a virtual learning environment. Journal of International Education in Business, 5(2), 114-128. 
Snell, M. E., \& Brown, F. (2000). Development and implementation of educational programs. In M. E. Snell \& F. Brown (Eds.), Instruction of students with severe disabilities (5th ed., pp. 115-172). Upper Saddle River, N.J.: Macmillan/Merrill.

Sun, P. A. (2008). What drives a successful e-Learning? An empirical investigation of the critical factors influencing learning satisfaction. Computers \& Education, 50(4), 11831202 .

Tiakiwai, S., \& Tiakiwai, H. (2010). A literature review focused on virtual learning environments (VLEs) and e-learning in the context of Te Reo Māori and Kaupapa Māori Education: Report to the Ministry of Education. Ministry of Education, New Zealand. Retrieved from http://thehub.superu.govt.nz/sites/default/files/42612_LitRevVLEs-FINALv2_0.pdf

Ursin, L., Lindsay, E. B., \& Johnson, C. M. (2004). Assessing library instruction in the freshman seminar: A citation analysis study. Reference Services Review, 32(3), 284292.

Wallace, M. C., Shorten, A., Crookes, P. A., McGurk, C., \& Brewer, C. (1999). Integrating information literacy into an undergraduate nursing program. Nursing Education Today, 19(2), 136-141.

Zhao, Z. (1996). Visualization of semantic relations between nodes in hypertext-based learning system. Doctoral dissertation, Open University, United Kingdom. 


\section{Appendix 1. Questionnaire for the Study of Integrated Information Literacy Teaching in Elementary Education Using a Virtual Learning Environment}

The purpose of the questionnaire is to collect data on the current status of information literacy instruction in schools, and the opinions of teachers on the components and factors for integrating information literacy teaching using a virtual learning environment (VLE) at the elementary education level. The questionnaire comprises 4 parts: 1) Information of the respondents, 2) Current status of IL instruction in school, 3) Components in integrating teaching using VLE, and 4) Factors for integrating teaching using VLE.

Please answer the questionnaire according to the facts of your school and the opinions you may have on each question. The data from the questionnaire will be confidentially analysed and reported.

PART I. Information of the respondent
1. Sex
[ ] Male
[ ] Female

2. Education [ ] Undergraduate degree [ ] Master's degree [ ] Doctoral degree

3. Academic position [ ] First level [ ] Second level [ ] Third level [ ] Fourth level

4. Teaching experiences [ ] 5-10 yrs [ ] 11-15 yrs. [ ] 16-20 yrs. [ ] >20 yrs.

5. Location of school (Please indicate the province)

6. Size of school [ ] Small (student population 1-120)

[ ] Medium (student population 121-600)

[ ] Large (student population 601-1,500)

[ ] Extra large (student population $>1,500$ )

\section{PART II. Current status of IL instruction in school}

\begin{tabular}{|c|c|}
\hline \multicolumn{2}{|c|}{ 1. What are the expected learning outcomes of the students in your course teaching? } \\
\hline$\square$ Awareness of self-value & $\square$ Ability to use computer technology \\
\hline$\square$ Possess of the global knowledge & $\square$ Ability of questioning \\
\hline$\square$ Possess of communication skills & $\square$ Ability of information evaluation \\
\hline$\square$ Possess of problem solving skills & $\square$ Ability of life-long learning \\
\hline$\square$ Possess of living skills & $\square$ Other \\
\hline \multicolumn{2}{|l|}{$\begin{array}{l}\square \text { Possess of critical and creative thinking } \\
\text { skills }\end{array}$} \\
\hline \multicolumn{2}{|c|}{$\begin{array}{l}\text { 2. What are the expected learning outcomes relating to the information literacy of the students } \\
\text { in your course teaching? }\end{array}$} \\
\hline$\square$ Identification of the study problems or topics & $\square$ Selection of information in according to the needs \\
\hline$\square$ Analysis of information needs & $\square$ Report and reference writing \\
\hline$\square$ Awareness of related information resources & $\square$ Use of information legally and ethically \\
\hline $\begin{array}{l}\square \text { Developing the search strategies and } \\
\text { techniques }\end{array}$ & $\square$ Other \\
\hline \multicolumn{2}{|c|}{$\begin{array}{l}\text { 3. Please indicate the activities that you have done collaboratively with the school's librarians in } \\
\text { the course teaching. }\end{array}$} \\
\hline$\square$ Development of the lesson plan & $\square$ Preparing of course instructional media \\
\hline $\begin{array}{l}\square \text { Assignment of the expected learning } \\
\text { outcomes }\end{array}$ & $\square$ Preparing of information resources \\
\hline$\square$ Assignment of the learning activities & $\square$ Teaching of IL skills \\
\hline$\square$ Preparing the exercises/home works & $\square$ Evaluation of IL skills \\
\hline$\square$ Identifying of expected IL skills & $\begin{array}{l}\square \text { other } \\
\ldots \ldots \ldots \ldots\end{array}$ \\
\hline
\end{tabular}




\begin{tabular}{|c|c|}
\hline $\begin{array}{l}\square \text { Preparing of computers and related } \\
\text { equipment }\end{array}$ & \\
\hline \multicolumn{2}{|c|}{ 4. Please indicate the teaching methods/approaches/techniques used in the course teaching. } \\
\hline$\square$ Lecture & $\square$ Problem-based, case studies \\
\hline$\square$ Demonstration & $\square$ Brain storming \\
\hline$\square$ Project-based learning & $\square$ Student-centered learning \\
\hline$\square$ Field trip & $\square$ Computer-assisted program \\
\hline$\square$ Group learning & $\begin{array}{l}\square \text { Other } \\
\ldots \ldots \ldots \ldots \ldots \ldots\end{array}$ \\
\hline \multicolumn{2}{|c|}{ 5. Please indicate the learning activities used in the course teaching. } \\
\hline$\square$ Library use orientation & $\square$ Group discussion \\
\hline$\square$ Library visit & $\square$ Study report presentation \\
\hline$\square$ Exercises/assignments & $\square \square$ Self-study assignment \\
\hline$\square$ Group project & $\square$ Other \\
\hline \multicolumn{2}{|c|}{ 6. Please indicate the information/learning resources used in the course teaching. } \\
\hline$\square$ Required textbooks & $\square$ Related media/audio visuals \\
\hline$\square$ Library resources & $\square$ Real sources (Person, places, organisation, etc.) \\
\hline$\square$ e-learning, web-based learning resources & $\begin{array}{l}\square \text { Other } \\
\ldots \ldots \ldots \ldots\end{array}$ \\
\hline
\end{tabular}

PART III. Components in integrating IL teaching using VLE

Please check $\checkmark$ in the table below to indicate your opinion on the components in integrating IL

teaching using VLE based on Likert's five scales: $5=$ very strongly agree to $1=$ very strongly disagree

\begin{tabular}{|l|l|l|l|l|l|l|}
\hline & Components & $\mathbf{5}$ & $\mathbf{4}$ & $\mathbf{3}$ & $\mathbf{2}$ & $\mathbf{1}$ \\
\hline $\mathbf{1 .}$ & Setting expected learning outcomes of elementary students & & & & & \\
\hline 1.1 & Students acknowledged of the importance and necessity of IL & & & & & \\
\hline 1.2 & Students having access to multiple information sources & & & & & \\
\hline 1.3 & $\begin{array}{l}\text { Students able to determine characteristics and scope of information } \\
\text { under their study topic }\end{array}$ & & & & \\
\hline 1.4 & $\begin{array}{l}\text { Students able to determine information searching/retrieving strategies } \\
\text { and improve the strategies to obtain the required information }\end{array}$ & & & & & \\
\hline 1.5 & Students able to use information retrieving tools & & & & & \\
\hline 1.6 & Students able to evaluate information and information resources & & & & \\
\hline 1.7 & Students able to analyse their retrieved information & & & & \\
\hline 1.8 & Students able to synthesise information to recreate new information & & & & & \\
\hline 1.9 & $\begin{array}{l}\text { Students able to make notes, compile, and organise retrieved } \\
\text { information }\end{array}$ & & & & & \\
\hline 1.10 & Students able draw important points of the retrieved information & & & & & \\
\hline 1.11 & $\begin{array}{l}\text { Students able to use information to do and present their assignment as } \\
\text { they wish }\end{array}$ & & & & & \\
\hline 1.12 & $\begin{array}{l}\text { Students able to learn, understand and use information ethically and } \\
\text { legally }\end{array}$ & & & & & \\
\hline $\mathbf{2 .}$ & Setting learning objectives & & & & & \\
\hline 2.1 & Having students participate directly in learning & & & & \\
\hline 2.2 & Having students aware that learning of everything is interrelated & & & & & \\
\hline 2.3 & Meeting students' interest by individualised learning & & & & & \\
\hline 2.4 & $\begin{array}{l}\text { Designing learning situations that allow students to learn } \\
\text { according to their needs more than to the curriculum }\end{array}$ & & & & & \\
\hline 2.5 & $\begin{array}{l}\text { Encouraging students to work with others through cooperative } \\
\text { learning approach }\end{array}$ & & & & & \\
\hline
\end{tabular}




\begin{tabular}{|c|c|c|c|c|c|c|}
\hline & Components & 5 & 4 & 3 & 2 & 1 \\
\hline 2.6 & $\begin{array}{l}\text { Focusing on holistic and continuous learning process rather than } \\
\text { learning each subject and skill separately }\end{array}$ & & & & & \\
\hline 2.7 & $\begin{array}{l}\text { Emphasising students' experiencing and transferring of required } \\
\text { knowledge and skills }\end{array}$ & & & & & \\
\hline 2.8 & $\begin{array}{l}\text { Connecting IL to instruction, learning, contents and evaluation of } \\
\text { course curriculum }\end{array}$ & & & & & \\
\hline 2.9 & $\begin{array}{l}\text { Problems or curriculum objectives related to IL instruction } \\
\text { clarified in elementary education }\end{array}$ & & & & & \\
\hline 2.10 & Objective being set that focuses on former IL skills & & & & & \\
\hline 3. & Managing learning contents & & & & & \\
\hline 3.1 & Having the curricula contents & & & & & \\
\hline 3.2 & $\begin{array}{l}\text { Having the contents that integrate IL by setting clear expected } \\
\text { learning outcomes }\end{array}$ & & & & & \\
\hline 3.3 & Providing examples for learners to understand more clearly & & & & & \\
\hline 3.4 & Updating information and revising subject's knowledge content & & & & & \\
\hline 3.5 & $\begin{array}{l}\text { Information should be dynamic and changing, and managed by } \\
\text { learners and teachers }\end{array}$ & & & & & \\
\hline 3.6 & $\begin{array}{l}\text { Presentation should be done using moving pictures so as to be } \\
\text { interesting to learners }\end{array}$ & & & & & \\
\hline 3.7 & $\begin{array}{l}\text { Providing downloading sources that are useful and related to the } \\
\text { instruction }\end{array}$ & & & & & \\
\hline 3.8 & $\begin{array}{l}\text { Information files should be sharable among the teacher, experts } \\
\text { and learners }\end{array}$ & & & & & \\
\hline 4. & Instruction & & & & & \\
\hline 4.1 & $\begin{array}{l}\text { Setting learning objectives that focus on development of IL skills } \\
\text { by assessing behaviors and outcomes that are related to the course }\end{array}$ & & & & & \\
\hline 4.2 & $\begin{array}{l}\text { Setting learning outcomes that focus on developing students' } \\
\text { moral and ethics in legal and decent use of information }\end{array}$ & & & & & \\
\hline 4.3 & $\begin{array}{l}\text { Having students selecting topics to study, search, analyse learning } \\
\text { points, and search information }\end{array}$ & & & & & \\
\hline 4.4 & $\begin{array}{l}\text { Setting teaching methods according to the subject content and } \\
\text { connecting IL to learning content }\end{array}$ & & & & & \\
\hline 4.5 & $\begin{array}{l}\text { Setting teaching media that focus on introduction of information } \\
\text { sources and information that connects subject contents with } \\
\text { assignments }\end{array}$ & & & & & \\
\hline 4.6 & $\begin{array}{l}\text { Assigning work and report of research study by incorporating the } \\
\text { assignment as part of the subject requirements }\end{array}$ & & & & & \\
\hline 4.7 & $\begin{array}{l}\text { Connecting curriculum with the goal/objectives of the national } \\
\text { education or Education Act }\end{array}$ & & & & & \\
\hline 4.8 & Setting objectives of IL that are suitable for elementary students & & & & & \\
\hline 5. & Teaching method using a VLE & & & & & \\
\hline 5.1 & Lecturing before learning & & & & & \\
\hline 5.2 & Demonstrating with emphasis on information searching & & & & & \\
\hline 5.3 & $\begin{array}{l}\text { Project-based teaching with students searching and using } \\
\text { information }\end{array}$ & & & & & \\
\hline 5.4 & Incorporating study trips at multiple learning resources & & & & & \\
\hline 5.5 & $\begin{array}{l}\text { Problem-based or case-based teaching with an emphasis on } \\
\text { students' searching and using information for studying and solving } \\
\text { problems }\end{array}$ & & & & & \\
\hline 5.6 & Incorporating brainstorming by setting the topics for studying, & & & & & \\
\hline
\end{tabular}




\begin{tabular}{|c|c|c|c|c|c|c|}
\hline & Components & 5 & 4 & 3 & 2 & 1 \\
\hline & analysing, and setting information retrieving strategies & & & & & \\
\hline 5.7 & Incorporating self-learning by searching on-line information & & & & & \\
\hline 5.8 & $\begin{array}{l}\text { Incorporating program-based lessons emphasising information } \\
\text { literacy content }\end{array}$ & & & & & \\
\hline 5.9 & $\begin{array}{l}\text { Incorporating critical-thinking teaching emphasising systematic } \\
\text { thinking, interpreting, categorising, and solving every-day } \\
\text { problems }\end{array}$ & & & & & \\
\hline 5.10 & $\begin{array}{l}\text { Incorporating cooperative learning with students divided into } \\
\text { small groups and emphasising cooperation in doing activities and } \\
\text { exchanging of opinions }\end{array}$ & & & & & \\
\hline 6. & Learning patterns & & & & & \\
\hline 6.1 & Synchronous learning & & & & & \\
\hline 6.2 & Asynchronous learning & & & & & \\
\hline 7. & Learning activities using virtual learning environment & & & & & \\
\hline 7.1 & $\begin{array}{l}\text { Having students do exercises and assignments from searching and } \\
\text { using of information }\end{array}$ & & & & & \\
\hline 7.2 & $\begin{array}{l}\text { Having students brainstorm to set topics to learn, analyse } \\
\text { information needs and determining retrieving strategies }\end{array}$ & & & & & \\
\hline 7.3 & $\begin{array}{l}\text { Focusing on self-learning and studying through information } \\
\text { survey, presenting information on the topic under study, and } \\
\text { recording the searched results }\end{array}$ & & & & & \\
\hline 7.4 & $\begin{array}{l}\text { Discussing and exchanging ideas among learners related to } \\
\text { experiences in information retrieval }\end{array}$ & & & & & \\
\hline 7.5 & Practice of information searching from online resources & & & & & \\
\hline 7.6 & $\begin{array}{l}\text { Posing and answering questions on searching, evaluating, and } \\
\text { connecting between IL and subject elements }\end{array}$ & & & & & \\
\hline 7.7 & $\begin{array}{l}\text { Teacher encouraging learners to show their ideas and respond to } \\
\text { the lessons and activities }\end{array}$ & & & & & \\
\hline 7.8 & $\begin{array}{l}\text { Having students write and present study reports through discussion } \\
\text { and exchange of ideas }\end{array}$ & & & & & \\
\hline 7.9 & $\begin{array}{l}\text { Students asking advice from teacher or librarians for information } \\
\text { retrieving and writing/using references }\end{array}$ & & & & & \\
\hline 7.10 & $\begin{array}{l}\text { Teacher and learners draw conclusions and usefulness for } \\
\text { everyday life from each topic together after learning }\end{array}$ & & & & & \\
\hline 8. & Teaching and learning interaction & & & & & \\
\hline 8.1 & Giving appropriate feedbacks & & & & & \\
\hline 8.2 & $\begin{array}{l}\text { The system capable in collecting and computing results of } \\
\text { dynamic information that arises }\end{array}$ & & & & & \\
\hline 8.3 & Channels or space provided for learners to interact & & & & & \\
\hline 8.4 & Providing supplementary teaching for students & & & & & \\
\hline 8.5 & Setting schedules for students to interact with other students & & & & & \\
\hline 8.6 & Setting schedules for students to interact with the teacher & & & & & \\
\hline 8.7 & $\begin{array}{l}\text { Setting clear rules and regulations for online classroom } \\
\text { communications }\end{array}$ & & & & & \\
\hline 8.8 & $\begin{array}{l}\text { Teacher able to regularly check and give suggestions on students' } \\
\text { work }\end{array}$ & & & & & \\
\hline 8.9 & $\begin{array}{l}\text { Teacher gives orientation to students before teaching, stating } \\
\text { objectives and instructing them to determine their topic to research }\end{array}$ & & & & & \\
\hline 8.10 & $\begin{array}{l}\text { Teacher poses simple questions to arouse learners to connect the } \\
\text { learning point to the information resources }\end{array}$ & & & & & \\
\hline
\end{tabular}




\begin{tabular}{|c|c|c|c|c|c|c|}
\hline & Components & 5 & 4 & 3 & 2 & $\mathbf{1}$ \\
\hline 8.11 & $\begin{array}{l}\text { Teacher encourages learners to give opinions and respond to the } \\
\text { lesson }\end{array}$ & & & & & \\
\hline 9. & Learning resources & & & & & \\
\hline 9.1 & $\begin{array}{l}\text { Resources that support learning interested academic topics or } \\
\text { assignments }\end{array}$ & & & & & \\
\hline 9.2 & Resources appropriate to students' age ranges and development & & & & & \\
\hline 9.3 & Resources for searching knowledge on interested topics in general & & & & & \\
\hline 9.4 & $\begin{array}{l}\text { Information sources for researching, retrieving news/movements/ } \\
\text { daily events }\end{array}$ & & & & & \\
\hline 9.5 & Sources of subject-related knowledge & & & & & \\
\hline 9.6 & $\begin{array}{l}\text { Information sources for entertainment such as songs, movies, } \\
\text { television programs, etc. }\end{array}$ & & & & & \\
\hline 10. & Learning assessment & & & & & \\
\hline 10.1 & $\begin{array}{l}\text { Setting assessment criteria focusing on students' development of } \\
\text { IL skills }\end{array}$ & & & & & \\
\hline 10.2 & $\begin{array}{l}\text { Assessing from exercises and assignments that have been done by } \\
\text { means of information searching to answer questions and solve } \\
\text { problems }\end{array}$ & & & & & \\
\hline 10.3 & $\begin{array}{l}\text { Assessing from report of an individual study, both from } \\
\text { presentation and referencing }\end{array}$ & & & & & \\
\hline 10.4 & $\begin{array}{l}\text { Assessing from small-group work by setting the topic to study, } \\
\text { analysing information needs, and setting retrieval strategies }\end{array}$ & & & & & \\
\hline 10.5 & Assessing from discussion and exchange of ideas & & & & & \\
\hline 10.6 & $\begin{array}{l}\text { Assessing from presentation of information obtained from self- } \\
\text { study }\end{array}$ & & & & & \\
\hline 10.7 & $\begin{array}{l}\text { Assessing from observation of the accurate, appropriate, ethical, } \\
\text { and legal use of information }\end{array}$ & & & & & \\
\hline 10.8 & $\begin{array}{l}\text { Concrete assessing of learning through pre- and post-tests, subject } \\
\text { assessment }\end{array}$ & & & & & \\
\hline 10.9 & $\begin{array}{l}\text { Assessing IL levels with questions linking between IL and subject } \\
\text { contents }\end{array}$ & & & & & \\
\hline
\end{tabular}

PART IV. Success factors for in integrating IL teaching using VLE

Please check $\checkmark$ in the table below to indicate your opinion on the success factors for integrating IL teaching using VLE based on Likert's five scales: $5=$ very strongly agree to $1=$ very strongly disagree

\begin{tabular}{|l|l|l|l|l|l|l|}
\hline & Factors & $\mathbf{5}$ & $\mathbf{4}$ & $\mathbf{3}$ & $\mathbf{2}$ & $\mathbf{1}$ \\
\hline $\mathbf{1 .}$ & Administrators & & & & & \\
\hline 1.1 & $\begin{array}{l}\text { Administrators see the importance of IL and set policy to support } \\
\text { this }\end{array}$ & & & & & \\
\hline 1.2 & $\begin{array}{l}\text { Administrators set policy and clear implementation methods to } \\
\text { support learners to become information literate }\end{array}$ & & & & & \\
\hline 1.3 & $\begin{array}{l}\text { Administrators set policy and clear implementation methods to } \\
\text { support electronics instruction }\end{array}$ & & & & & \\
\hline 1.4 & $\begin{array}{l}\text { Administrators monitor the integration of IL to be in accordance } \\
\text { with learners' IL skills }\end{array}$ & & & & \\
\hline 1.5 & $\begin{array}{l}\text { Administrators build chances for cooperation between teachers } \\
\text { and librarians to link IL with subject contents }\end{array}$ & & & & \\
\hline 1.6 & $\begin{array}{l}\text { Administrators support teaching and activities related to } \\
\text { integration of IL }\end{array}$ & & & & \\
\hline
\end{tabular}




\begin{tabular}{|c|c|c|c|c|c|c|}
\hline & Factors & 5 & 4 & 3 & 2 & $\mathbf{1}$ \\
\hline 1.7 & Administrators support in terms of developmental infrastructures & & & & & \\
\hline 1.8 & $\begin{array}{l}\text { Administrators support in terms of administration and budget for } \\
\text { improving various learning resources }\end{array}$ & & & & & \\
\hline 2. & Teacher & & & & & \\
\hline 2.1 & The teacher knows and is capable in the use of IT & & & & & \\
\hline 2.2 & $\begin{array}{l}\text { The teacher must be able to improve the instruction by } \\
\text { continuously using VLE }\end{array}$ & & & & & \\
\hline 2.3 & $\begin{array}{l}\text { The teacher must dedicate his/her time for organising instruction } \\
\text { via a VLE }\end{array}$ & & & & & \\
\hline 2.4 & The teacher sees the importance of IL & & & & & \\
\hline 2.5 & $\begin{array}{l}\text { The teacher understands and is able to integrate IL with } \\
\text { instruction }\end{array}$ & & & & & \\
\hline 2.6 & The teacher knows multiple sources of information & & & & & \\
\hline 3. & Cooperation of librarians & & & & & \\
\hline 3.1 & $\begin{array}{l}\text { Librarians should participate with the teacher from curriculum } \\
\text { design, teaching planning, planning activities and assessment }\end{array}$ & & & & & \\
\hline 3.2 & Librarians know and are capable in the use of IT & & & & & \\
\hline 3.3 & Librarians see the importance of IL & & & & & \\
\hline 3.4 & Librarians understand and are able to integrate IL in instruction & & & & & \\
\hline 4. & Learners & & & & & \\
\hline 4.1 & Learners have experience learning via online classrooms. & & & & & \\
\hline 4.2 & Learners know and are able to use IT & & & & & \\
\hline 4.3 & $\begin{array}{l}\text { Learners share experiences together, analyse information, and } \\
\text { select it before sharing }\end{array}$ & & & & & \\
\hline 4.4 & $\begin{array}{l}\text { Learners must be capable in controlling their learning time frame } \\
\text { efficiently }\end{array}$ & & & & & \\
\hline 5 & Teacher and learners interactions & & & & & \\
\hline 5.1 & $\begin{array}{l}\text { Relationships between the teacher and students directly affect the } \\
\text { success of learning activities }\end{array}$ & & & & & \\
\hline 5.2 & Relationships between the teacher and students must be positive & & & & & \\
\hline 5.3 & $\begin{array}{l}\text { Students are able to ask and answer questions with the teacher } \\
\text { under good relationships }\end{array}$ & & & & & \\
\hline 5.4 & $\begin{array}{l}\text { The fact that students relate stories to others and unscramble } \\
\text { things together enables development of analytical thinking skill }\end{array}$ & & & & & \\
\hline 5.5 & $\begin{array}{l}\text { Discussion results in learners' development of critical thinking } \\
\text { skill }\end{array}$ & & & & & \\
\hline 5.6 & $\begin{array}{l}\text { The learner-supporting system enables the teacher to arrange } \\
\text { online time for learners to chat and consult }\end{array}$ & & & & & \\
\hline 5.7 & $\begin{array}{l}\text { The teacher has clear online time-table and meets students in the } \\
\text { room regularly }\end{array}$ & & & & & \\
\hline 6. & Instructional activities & & & & & \\
\hline 6.1 & The group leader needs to be strong & & & & & \\
\hline 6.2 & $\begin{array}{l}\text { Group members must attend classes and participate in activities } \\
\text { regularly }\end{array}$ & & & & & \\
\hline 6.3 & Activities must cover all information literacy skills & & & & & \\
\hline 6.4 & $\begin{array}{l}\text { Analytical thinking assignment should be provided with adequate } \\
\text { time for students to contemplate and practice thinking }\end{array}$ & & & & & \\
\hline 6.5 & $\begin{array}{l}\text { Activities should be suitable to students' intellectual level, or not } \\
\text { being too difficult }\end{array}$ & & & & & \\
\hline 6.6 & Activities should be of various sorts and interesting & & & & & \\
\hline
\end{tabular}


-ibres volume 25, issue 1, pages 50-77 (2015)

\begin{tabular}{|l|l|l|l|l|l|l|}
\hline & Factors & $\mathbf{5}$ & $\mathbf{4}$ & $\mathbf{3}$ & $\mathbf{2}$ & $\mathbf{1}$ \\
\hline 6.7 & $\begin{array}{l}\text { Learners should be encouraged to use multiple information for } \\
\text { their learning }\end{array}$ & & & & & \\
\hline 6.8 & $\begin{array}{l}\text { Learners should be encouraged to interact with the teacher and } \\
\text { other learners through the learning system such as chatting, e- } \\
\text { mail, board, etc. }\end{array}$ & & & & & \\
\hline 6.9 & $\begin{array}{l}\text { Learners should be encouraged to use all IL skills according to the } \\
\text { standard }\end{array}$ & & & & \\
\hline $\mathbf{7 .}$ & Quality of technology & & & & \\
\hline 7.1 & $\begin{array}{l}\text { The computer qualities are appropriate to the high-speed Internet } \\
\text { network }\end{array}$ & & & & \\
\hline 7.2 & $\begin{array}{l}\text { There is the high-speed Internet network which is not often down } \\
\text { or does not often face connection problem }\end{array}$ & & & & & \\
\hline 7.3 & A VLE can be linked efficiently to external information sources & & & & & \\
\hline 7.4 & $\begin{array}{l}\text { The system can respond to the learning abilities of learners, and } \\
\text { can be used everywhere and all the time }\end{array}$ & & & & & \\
\hline 7.5 & The software is used efficiently to support communications & & & & & \\
\hline 7.6 & $\begin{array}{l}\text { Multiple programs supporting learning are provided such as media } \\
\text { player, Acrobat, search engine, etc. }\end{array}$ & & & & & \\
\hline 7.7 & Digital divide should be taken into account & & & & \\
\hline 7.8 & $\begin{array}{l}\text { The system for compiling and computing movements of } \\
\text { information is available }\end{array}$ & & & & & \\
\hline 7.9 & Usage is simple, with press button menu as appropriate & & & & \\
\hline 7.10 & Information can be computed and shown & $\begin{array}{l}\text { Feedback is spontaneous, and there is warning when learners } \\
\text { make a mistake }\end{array}$ & & & & \\
\hline 7.11 & & & & & \\
\hline
\end{tabular}

Additional suggestions or

comments. 
Appendix 2. The components that enhance integration of information literacy instruction in course teaching using a virtual learning environment (results of explorative factor analysis)

\begin{tabular}{|c|c|c|c|c|}
\hline Components & Sub-components & $\overline{\boldsymbol{X}}$ & S.D. & $\begin{array}{l}\text { Factor } \\
\text { loading } \\
\text { value }\end{array}$ \\
\hline \multirow{14}{*}{$\begin{array}{l}\text { 1. Setting } \\
\text { expected } \\
\text { learning } \\
\text { outcomes of } \\
\text { elementary } \\
\text { students }\end{array}$} & 1. Students acknowledge the importance and necessity of IL & 4.05 & 0.69 & 0.607 \\
\hline & 2. Students have access to multiple information sources & 3.97 & 0.76 & 0.653 \\
\hline & $\begin{array}{l}\text { 3. Students able to determine characteristics and scope of } \\
\text { information under their study topic }\end{array}$ & 3.79 & 0.76 & 0.681 \\
\hline & $\begin{array}{l}\text { 4. Students able to determine information searching/retrieving } \\
\text { strategies and improve the strategies to obtain the required } \\
\text { information }\end{array}$ & 3.72 & 0.80 & 0.733 \\
\hline & 5. Students able to use information retrieving tools & 3.97 & 0.77 & 0.711 \\
\hline & 6. Students able to evaluate information and information resources & 3.68 & 0.78 & 0.773 \\
\hline & 7. Students able to analyze their retrieved information & 3.68 & 0.82 & 0.796 \\
\hline & $\begin{array}{l}\text { 8. Students able to synthesize information to recreate new } \\
\text { information }\end{array}$ & 3.41 & 0.89 & 0.778 \\
\hline & $\begin{array}{l}\text { 9. Students able to make notes, compile, and organize retrieved } \\
\text { information }\end{array}$ & 3.77 & 0.80 & 0.697 \\
\hline & 10. Students able draw important points of the retrieved information & 3.80 & 0.79 & 0.726 \\
\hline & $\begin{array}{l}\text { 11. Students able to use information to do and present their } \\
\text { assignment as they wish }\end{array}$ & 3.73 & 0.83 & 0.762 \\
\hline & $\begin{array}{l}\text { 12. Students able to learn, understand and use information ethically } \\
\text { and legally }\end{array}$ & 3.88 & 0.80 & 0.633 \\
\hline & $\begin{array}{l}\text { 13. Problems or curriculum objectives related to IL instruction } \\
\text { clarified in elementary education }\end{array}$ & 4.06 & 0.71 & 0.473 \\
\hline & 14. Objective being set th & 3.98 & 0.69 & 0.443 \\
\hline \multirow{8}{*}{$\begin{array}{l}\text { 2. Setting } \\
\text { learning } \\
\text { objectives }\end{array}$} & 1. Having students participate direct & 4.05 & 0.65 & 0.515 \\
\hline & $\begin{array}{l}\text { 2. Having students aware that learning of everything is } \\
\text { interrelated }\end{array}$ & 4.02 & 0.65 & 644 \\
\hline & 3. Meeting students' interest by individualized learning & 4.01 & 0.71 & 0.611 \\
\hline & $\begin{array}{l}\text { 4. Designing learning situations that allow students to learn } \\
\text { according to their needs more than to the curriculum }\end{array}$ & 3.82 & 0.75 & 0.627 \\
\hline & $\begin{array}{l}\text { 5. Encouraging students to work with others through } \\
\text { cooperative learning approach }\end{array}$ & 4.19 & 0.67 & 0.660 \\
\hline & $\begin{array}{l}\text { 6. Focusing on holistic and continuous learning process rather } \\
\text { than learning each subject and skill separately }\end{array}$ & 3.99 & 0.66 & 0.691 \\
\hline & $\begin{array}{l}\text { 7. Emphasizing students' experiencing and transferring of } \\
\text { required knowledge and skills }\end{array}$ & 4.03 & 0.69 & 0.618 \\
\hline & $\begin{array}{l}\text { 8. Connecting IL to instruction, learning, contents and } \\
\text { evaluation of course curriculum }\end{array}$ & 4.05 & 0.67 & 0.558 \\
\hline \multirow{10}{*}{$\begin{array}{l}\text { 3. Managing } \\
\text { learning } \\
\text { contents }\end{array}$} & 1. Having the curricula contents & 4.27 & 0.62 & 0.666 \\
\hline & $\begin{array}{l}\text { 2. Having the contents that integrate IL by setting clear } \\
\text { expected learning outcomes }\end{array}$ & 4.24 & 0.65 & 0.688 \\
\hline & 3. Providing examples for learners to understand more clearly & 4.26 & 0.63 & 0.709 \\
\hline & $\begin{array}{l}\text { 4. Updating information and revising subject's knowledge } \\
\text { content }\end{array}$ & 4.21 & 0.63 & 0.700 \\
\hline & $\begin{array}{l}\text { 5. Information should be dynamic and changing, and managed } \\
\text { by learners and teachers. }\end{array}$ & 4.17 & 0.69 & 0.671 \\
\hline & $\begin{array}{l}\text { 6. Presentation should be done using moving pictures so as to } \\
\text { be interesting to learners }\end{array}$ & 4.10 & 0.74 & 0.593 \\
\hline & $\begin{array}{l}\text { 7. Providing downloading sources that are useful and related to } \\
\text { the instruction }\end{array}$ & 4.06 & 0.81 & 0.617 \\
\hline & $\begin{array}{l}\text { 8. Information files should be sharable among the teacher, } \\
\text { experts and learners. }\end{array}$ & 3.90 & 0.87 & 0.511 \\
\hline & $\begin{array}{l}\text { 9. Connecting curriculum with the goal/objectives of the } \\
\text { national education or Education Act }\end{array}$ & 4.15 & 0.71 & 0.481 \\
\hline & 10. Setting objectives of IL that are suitable for elementary & 4.12 & 0.70 & 0.490 \\
\hline
\end{tabular}




\begin{tabular}{|c|c|c|c|c|}
\hline Components & Sub-components & $\overline{\boldsymbol{X}}$ & S.D. & $\begin{array}{l}\text { Factor } \\
\text { loading } \\
\text { value }\end{array}$ \\
\hline & students & & & \\
\hline \multirow[t]{6}{*}{ 4. Instruction } & $\begin{array}{l}\text { 1. Setting learning objectives that focus on development of IL } \\
\text { skills by assessing behaviors and outcomes that are related } \\
\text { to the course }\end{array}$ & 4.06 & 0.69 & 0.618 \\
\hline & $\begin{array}{l}\text { 2. Setting learning outcomes that focus on developing students' } \\
\text { moral and ethics in legal and decent use of information }\end{array}$ & 4.12 & 0.67 & 0.628 \\
\hline & $\begin{array}{l}\text { 3. Having students selecting topics to study, search, analyze } \\
\text { learning points, and search information }\end{array}$ & 4.00 & 0.73 & 0.609 \\
\hline & $\begin{array}{l}\text { 4. Setting teaching methods according to the subject content } \\
\text { and connecting IL to learning content }\end{array}$ & 4.08 & 0.68 & 0.573 \\
\hline & $\begin{array}{l}\text { 5. Setting teaching media that focus on introduction of } \\
\text { information sources and information that connects subject } \\
\text { contents with assignments }\end{array}$ & 4.06 & 0.71 & 0.560 \\
\hline & $\begin{array}{l}\text { 6. Assigning work and report of research study by } \\
\text { incorporating the assignment as part of the subject } \\
\text { requirements }\end{array}$ & 4.05 & 0.70 & 0.457 \\
\hline \multirow{10}{*}{$\begin{array}{l}\text { 5. Teaching } \\
\text { method using } \\
\text { a VLE }\end{array}$} & 1. Lecturing before learning & 3.94 & 0.75 & 0.742 \\
\hline & 2. Demonstrating with emphasis on information searching & 4.03 & 0.76 & 0.455 \\
\hline & $\begin{array}{l}\text { 3. Project-based teaching with students searching and using } \\
\text { information }\end{array}$ & 4.02 & 0.83 & 0.518 \\
\hline & 4. Incorporating study trips at multiple learning resources & 4.07 & 0.78 & 0.608 \\
\hline & $\begin{array}{l}\text { 5. Problem-based or case-based teaching with an emphasis on } \\
\text { students' searching and using information for studying and } \\
\text { solving problems }\end{array}$ & 3.95 & 0.75 & 0.685 \\
\hline & $\begin{array}{l}\text { 6. Incorporating brainstorming by setting the topics for } \\
\text { studying, analyzing, and setting information retrieving } \\
\text { strategies }\end{array}$ & 3.98 & 0.74 & 0.697 \\
\hline & 7. Incorporating self-learning by searching on-line information & 4.07 & 0.76 & 0.605 \\
\hline & $\begin{array}{l}\text { 8. Incorporating program-based lessons emphasizing } \\
\text { information literacy content }\end{array}$ & 3.71 & 0.85 & 0.457 \\
\hline & $\begin{array}{l}\text { 9. Incorporating critical-thinking teaching emphasizing } \\
\text { systematic thinking, interpreting, categorizing, and solving } \\
\text { every-day problems }\end{array}$ & 4.00 & 0.79 & 0.627 \\
\hline & $\begin{array}{l}\text { 10. Incorporating cooperative learning with students divided } \\
\text { into small groups and emphasizing cooperation in doing } \\
\text { activities and exchanging of opinions }\end{array}$ & 4.09 & 0.75 & 0.554 \\
\hline \multirow{2}{*}{$\begin{array}{l}\text { 6. Learning } \\
\text { patterns }\end{array}$} & 1. Synchronous learning & 3.65 & 1.00 & 0.587 \\
\hline & 2. Asynchronous learning & 3.48 & 0.98 & 0.665 \\
\hline \multirow{9}{*}{$\begin{array}{l}\text { 7. Learning } \\
\text { activities } \\
\text { using virtual } \\
\text { learning } \\
\text { environment }\end{array}$} & $\begin{array}{l}\text { 1. Having students do exercises and assignments from } \\
\text { searching and using of information }\end{array}$ & 4.05 & 0.75 & 0.446 \\
\hline & $\begin{array}{l}\text { 2. Having students brainstorm to set topics to learn, analyze } \\
\text { information needs and determining retrieving strategies }\end{array}$ & 4.03 & 0.75 & 0.400 \\
\hline & $\begin{array}{l}\text { 3. Focusing on self-learning and studying through information } \\
\text { survey, presenting information on the topic under study, and } \\
\text { recording the searched results }\end{array}$ & 4.06 & 0.81 & 0.460 \\
\hline & $\begin{array}{l}\text { 4. Discussing and exchanging ideas among learners related to } \\
\text { experiences in information retrieval }\end{array}$ & 4.01 & 0.74 & 0.480 \\
\hline & 5. Practice of information searching from online resources & 3.91 & 0.86 & 0.431 \\
\hline & $\begin{array}{l}\text { 6. Posing and answering questions on searching, evaluating, } \\
\text { and connecting between IL and subject elements }\end{array}$ & 3.94 & 0.76 & 0.428 \\
\hline & $\begin{array}{l}\text { 7. Teacher encouraging learners to show their ideas and } \\
\text { respond to the lessons and activities }\end{array}$ & 4.13 & 0.73 & 0.368 \\
\hline & $\begin{array}{l}\text { 8. Having students write and present study reports through } \\
\text { discussion and exchange of ideas }\end{array}$ & 4.04 & 0.71 & 0.392 \\
\hline & $\begin{array}{l}\text { 9. Students asking advice from teacher or librarians for } \\
\text { information retrieving and writing/using references }\end{array}$ & 3.90 & 0.75 & 0.447 \\
\hline
\end{tabular}




\begin{tabular}{|c|c|c|c|c|}
\hline Components & Sub-components & $\overline{\boldsymbol{X}}$ & S.D. & $\begin{array}{l}\text { Factor } \\
\text { loading } \\
\text { value }\end{array}$ \\
\hline \multirow{8}{*}{$\begin{array}{l}\text { 8. Teaching } \\
\text { and learning } \\
\text { interaction }\end{array}$} & 1. Giving appropriate feedbacks & 4.18 & 0.65 & 0.448 \\
\hline & $\begin{array}{l}\text { 2. The system capable in collecting and computing results of } \\
\text { dynamic information that arises }\end{array}$ & 3.99 & 0.75 & 0.584 \\
\hline & 3. Channels or space provided for learners to interact & 4.03 & 0.72 & 0.566 \\
\hline & 4. Providing supplementary teaching for students & 4.01 & 0.71 & 0.608 \\
\hline & 5. Setting schedules for students to interact with other students & 3.94 & 0.74 & 0.741 \\
\hline & 6. Setting schedules for students to interact with the teacher & 3.98 & 0.71 & 0.673 \\
\hline & $\begin{array}{l}\text { 7. Setting clear rules and regulations for online classroom } \\
\text { communications }\end{array}$ & 3.90 & 0.82 & 0.593 \\
\hline & $\begin{array}{l}\text { 8. Teacher able to regularly check and give suggestions on } \\
\text { students' work }\end{array}$ & 4.10 & 0.74 & 0.449 \\
\hline \multirow[t]{6}{*}{$\begin{array}{l}\text { 9. Learning } \\
\text { resources }\end{array}$} & $\begin{array}{l}\text { 1. Resources that support learning interested academic topics } \\
\text { or assignments }\end{array}$ & 4.09 & 0.71 & 0.468 \\
\hline & $\begin{array}{l}\text { 2. Resources appropriate to students' age ranges and } \\
\text { development }\end{array}$ & 4.08 & 0.74 & 0.539 \\
\hline & $\begin{array}{l}\text { 3. Resources for searching knowledge on interested topics in } \\
\text { general }\end{array}$ & 4.02 & 0.71 & 0.647 \\
\hline & $\begin{array}{l}\text { 4. Information sources for researching, retrieving } \\
\text { news/movements/ daily events }\end{array}$ & 4.05 & 0.73 & 0.577 \\
\hline & 5. Sources of subject-related knowledge & 3.93 & 0.78 & 0.583 \\
\hline & $\begin{array}{l}\text { 6. Information sources for entertainment such as songs, movies, } \\
\text { television programs, etc. }\end{array}$ & 3.89 & 0.81 & 0.588 \\
\hline \multirow[t]{9}{*}{$\begin{array}{l}\text { 10. Learning } \\
\text { assessment }\end{array}$} & $\begin{array}{l}\text { 1. Setting assessment criteria focusing on students' } \\
\text { development of IL skills }\end{array}$ & 4.15 & 0.71 & 0.566 \\
\hline & $\begin{array}{l}\text { 2. Assessing from exercises and assignments that have been } \\
\text { done by means of information searching to answer questions } \\
\text { and solve problems }\end{array}$ & 4.12 & 0.70 & 0.710 \\
\hline & $\begin{array}{l}\text { 3. Assessing from report of an individual study, both from } \\
\text { presentation and referencing }\end{array}$ & 4.05 & 0.72 & 0.691 \\
\hline & $\begin{array}{l}\text { 4. Assessing from small-group work by setting the topic to } \\
\text { study, analyzing information needs, and setting retrieval } \\
\text { strategies }\end{array}$ & 4.07 & 0.70 & 0.618 \\
\hline & 5. Assessing from discussion and exchange of ideas & 4.03 & 0.70 & 0.632 \\
\hline & $\begin{array}{l}\text { 6. Assessing from presentation of information obtained from } \\
\text { self-study }\end{array}$ & 4.05 & 0.72 & 0.601 \\
\hline & $\begin{array}{l}\text { 7. Assessing from observation of the accurate, appropriate, } \\
\text { ethical, and legal use of information }\end{array}$ & 4.14 & 0.70 & 0.620 \\
\hline & $\begin{array}{l}\text { 8. Concrete assessing of learning through pre- and post-tests, } \\
\text { subject assessment }\end{array}$ & 4.20 & 0.69 & 0.590 \\
\hline & $\begin{array}{l}\text { 9. Assessing IL levels with questions linking between IL and } \\
\text { subject contents }\end{array}$ & 4.09 & 0.69 & 0.498 \\
\hline \multirow[t]{4}{*}{$\begin{array}{l}\text { 11. Teaching } \\
\text { strategies }\end{array}$} & $\begin{array}{l}\text { 1. Teacher and learners draw conclusions and usefulness for } \\
\text { everyday life from each topic together after learning }\end{array}$ & 4.11 & 0.74 & 0.474 \\
\hline & $\begin{array}{l}\text { 2. Teacher gives orientation to students before teaching, stating } \\
\text { objectives and instructing them to determine their topic to } \\
\text { research }\end{array}$ & 4.27 & 0.71 & 0.553 \\
\hline & $\begin{array}{l}\text { 3. Teacher poses simple questions to arouse learners to connect } \\
\text { the learning point to the information resources }\end{array}$ & 4.24 & 0.70 & 0.524 \\
\hline & $\begin{array}{l}\text { 4. Teacher encourages learners to give opinions and respond to } \\
\text { the lesson }\end{array}$ & 4.22 & 0.63 & 0.415 \\
\hline
\end{tabular}


Appendix 3. The success factors that enhance integration of information literacy instruction using a virtual learning environment (results of exploratory factor analysis)

\begin{tabular}{|c|c|c|c|c|}
\hline Factors & Sub-Factors & $\overline{\bar{X}}$ & S.D. & $\begin{array}{l}\text { Factor } \\
\text { loading } \\
\text { value }\end{array}$ \\
\hline \multirow[t]{8}{*}{ 1. Administrators } & $\begin{array}{l}\text { 1. Administrators see the importance of IL and set policy to } \\
\text { support this }\end{array}$ & 4.29 & 0.71 & 0.698 \\
\hline & $\begin{array}{l}\text { 2. Administrators set policy and clear implementation } \\
\text { methods to support learners to become information } \\
\text { literate }\end{array}$ & 4.24 & 0.70 & 0.722 \\
\hline & $\begin{array}{l}\text { 3. Administrators set policy and clear implementation } \\
\text { methods to support electronics instruction }\end{array}$ & 4.22 & 0.73 & 0.772 \\
\hline & $\begin{array}{l}\text { 4. Administrators monitor the integration of IL to be in } \\
\text { accordance with learners' IL skills }\end{array}$ & 4.08 & 0.77 & 0.782 \\
\hline & $\begin{array}{l}\text { 5. Administrators build chances for cooperation between } \\
\text { teachers and librarians to link IL with subject contents }\end{array}$ & 4.10 & 0.78 & 0.789 \\
\hline & $\begin{array}{l}\text { 6. Administrators support teaching and activities related to } \\
\text { integration of IL }\end{array}$ & 4.18 & 0.72 & 0.803 \\
\hline & $\begin{array}{l}\text { 7. Administrators support in terms of developmental } \\
\text { infrastructures }\end{array}$ & 4.28 & 0.75 & 0.746 \\
\hline & $\begin{array}{l}\text { 8. Administrators support in terms of administration and } \\
\text { budget for improving various learning resources }\end{array}$ & 4.27 & 0.72 & 0.746 \\
\hline \multirow[t]{6}{*}{ 2. Teacher } & 1. The teacher knows and is capable in the use of IT & 4.09 & 0.77 & 0.599 \\
\hline & $\begin{array}{l}\text { 2. The teacher must be able to improve the instruction by } \\
\text { continuously using VLE }\end{array}$ & 4.10 & 0.75 & 0.630 \\
\hline & $\begin{array}{l}\text { 3. The teacher must dedicate his/her time for organizing } \\
\text { instruction via a VLE }\end{array}$ & 4.03 & 0.82 & 0.649 \\
\hline & 4. The teacher sees the importance of IL & 4.21 & 0.74 & 0.709 \\
\hline & $\begin{array}{l}\text { 5. The teacher understands and is able to integrate IL with } \\
\text { instruction }\end{array}$ & 4.13 & 0.74 & 0.692 \\
\hline & 6. The teacher knows multiple sources of information & 4.19 & 0.78 & 0.616 \\
\hline \multirow[t]{4}{*}{$\begin{array}{l}\text { 3. Cooperation } \\
\text { of librarians }\end{array}$} & $\begin{array}{l}\text { 1. Librarians should participate with the teacher from } \\
\text { curriculum design, teaching planning, planning activities } \\
\text { and assessment }\end{array}$ & 3.89 & 0.81 & 0.713 \\
\hline & 2. Librarians know and are capable in the use of IT & 3.92 & 0.85 & 0.724 \\
\hline & 3. Librarians see the importance of IL & 4.01 & 0.82 & 0.783 \\
\hline & $\begin{array}{l}\text { 4. Librarians understand and are able to integrate IL in } \\
\text { instruction }\end{array}$ & 3.96 & 0.82 & 0.748 \\
\hline \multirow[t]{4}{*}{.4Learners } & 1. Learners have experience learning via online classrooms. & 3.59 & 1.01 & 0.797 \\
\hline & 2. Learners know and are able to use IT & 3.73 & 0.93 & 0.747 \\
\hline & $\begin{array}{l}\text { 3. Learners share experiences together, analyze } \\
\text { information, and select it before sharing }\end{array}$ & 3.80 & 0.90 & 0.721 \\
\hline & $\begin{array}{l}\text { 4. Learners must be capable in controlling their learning } \\
\text { time frame efficiently }\end{array}$ & 3.89 & 0.81 & 0.606 \\
\hline \multirow{6}{*}{$\begin{array}{l}.5 \text { Teacher and } \\
\text { learners } \\
\text { interactions }\end{array}$} & $\begin{array}{l}\text { 1. Relationships between the teacher and students directly } \\
\text { affect the success of learning activities }\end{array}$ & 4.19 & 0.71 & 0.609 \\
\hline & $\begin{array}{l}\text { 2. Relationships between the teacher and students must be } \\
\text { positive }\end{array}$ & 4.27 & 0.67 & 0.691 \\
\hline & $\begin{array}{l}\text { 3. Students are able to ask and answer questions with the } \\
\text { teacher under good relationships }\end{array}$ & 4.19 & 0.67 & 0.692 \\
\hline & $\begin{array}{l}\text { 4. The fact that students relate stories to others and } \\
\text { unscramble things together enables development of } \\
\text { analytical thinking skill }\end{array}$ & 4.03 & 0.74 & 0.616 \\
\hline & $\begin{array}{l}\text { 5. Discussion results in learners' development of critical } \\
\text { thinking skill }\end{array}$ & 4.04 & 0.72 & 0.616 \\
\hline & $\begin{array}{l}\text { 6. The learner-supporting system enables the teacher to } \\
\text { arrange online time for learners to chat and consult }\end{array}$ & 4.04 & 0.79 & 0.476 \\
\hline
\end{tabular}




\begin{tabular}{|c|c|c|c|c|}
\hline Factors & Sub-Factors & $\overline{\boldsymbol{X}}$ & S.D. & $\begin{array}{l}\text { Factor } \\
\text { loading } \\
\text { value }\end{array}$ \\
\hline & $\begin{array}{l}\text { 7. The teacher has clear online time-table and meets } \\
\text { students in the room regularly }\end{array}$ & 3.97 & 0.85 & 0.420 \\
\hline \multirow{9}{*}{$\begin{array}{l}\text { 6. Instructional } \\
\text { activities }\end{array}$} & 1. The group leader needs to be strong & 4.11 & 0.76 & 0.615 \\
\hline & $\begin{array}{l}\text { 2. Group members must attend classes and participate in } \\
\text { activities regularly }\end{array}$ & 4.21 & 0.71 & 0.630 \\
\hline & 3. Activities must cover all information literacy skills & 4.11 & 0.75 & 0.628 \\
\hline & $\begin{array}{l}\text { 4. Analytical thinking assignment should be provided with } \\
\text { adequate time for students to contemplate and practice } \\
\text { thinking }\end{array}$ & 4.08 & 0.72 & 0.589 \\
\hline & $\begin{array}{l}\text { 5. Activities should be suitable to students' intellectual } \\
\text { level, or not being too difficult }\end{array}$ & 4.22 & 0.66 & 0.657 \\
\hline & 6. Activities should be of various sorts and interesting & 4.23 & 0.70 & 0.707 \\
\hline & $\begin{array}{l}\text { 7. Learners should be encouraged to use multiple } \\
\text { information for their learning }\end{array}$ & 4.18 & 0.69 & 0.741 \\
\hline & $\begin{array}{l}\text { 8. Learners should be encouraged to interact with the } \\
\text { teacher and other learners through the learning system } \\
\text { such as chatting, e-mail, board, etc. }\end{array}$ & 4.02 & 0.81 & 0.594 \\
\hline & $\begin{array}{l}\text { 9. Learners should be encouraged to use all IL skills } \\
\text { according to the standard }\end{array}$ & 4.09 & 0.76 & 0.629 \\
\hline \multirow[t]{11}{*}{$\begin{array}{l}\text { 7. Quality of } \\
\text { technology }\end{array}$} & $\begin{array}{l}\text { 1. The computer qualities are appropriate to the high-speed } \\
\text { internet network }\end{array}$ & 4.18 & 0.87 & 0.615 \\
\hline & $\begin{array}{l}\text { 2. There is the high-speed internet network which is not } \\
\text { often down or does not often face connection problem }\end{array}$ & 4.18 & 0.90 & 0.630 \\
\hline & $\begin{array}{l}\text { 3. A VLE can be linked efficiently to external information } \\
\text { sources }\end{array}$ & 4.12 & 0.95 & 0.628 \\
\hline & $\begin{array}{l}\text { 4. The system can respond to the learning abilities of } \\
\text { learners, and can be used everywhere and all the time }\end{array}$ & 4.13 & 0.90 & 0.589 \\
\hline & $\begin{array}{l}\text { 5. The software is used efficiently to support } \\
\text { communications }\end{array}$ & 4.08 & 0.93 & 0.657 \\
\hline & $\begin{array}{l}\text { 6. Multiple programs supporting learning are provided such } \\
\text { as media player, Acrobat, search engine, etc. }\end{array}$ & 4.03 & 0.96 & 0.657 \\
\hline & 7. Digital divide should be taken into account & 3.96 & 0.90 & 0.707 \\
\hline & $\begin{array}{l}\text { 8. The system for compiling and computing movements of } \\
\text { information is available }\end{array}$ & 3.99 & 0.88 & 0.741 \\
\hline & 9. Usage is simple, with press button menu as appropriate & 4.06 & 0.90 & 0.594 \\
\hline & 10. Information can be computed and shown & 4.04 & 0.89 & 0.629 \\
\hline & $\begin{array}{l}\text { 11. Feedback is spontaneous, and there is warning when } \\
\text { learners make a mistake }\end{array}$ & 4.02 & 0.92 & 0.657 \\
\hline
\end{tabular}

